\title{
PENGARUH KEBERAKSARAAN PADA TEMA KEMELAYUAN DALAM SAJAK BEBERAPA PENYAIR RIAU (SEBUAH DUGAAN)
}

\author{
Alvi Puspita \\ Universitas Lancang Kuning, Pekanbaru \\ alvipuspita1003@gmail.com
}

\begin{abstract}
Reading a number of works by Riau poets, at least some of the same things felt. Especially in nuances and thematic namely gloom, anger and maleness. This paper tries to explain one of the alleged causes of this, namely the issue of literacy. That the coming of literacy also brings new perspectives in seeing 'self' and 'outside of ourselves' as contained in cultural products, one of which is literary work. Taufik Ikram Jamil and Marhalim Zaini are two Riau poets whose work was discussed in this paper.
\end{abstract}

Keywords: Riau Poets, Malay

\section{PENDAHULUAN}

Media menurut Danesi (2010: 2), secara umum bisa didefinisikan sebagai cara fisik bagaimana suatu sistem 'tanda' (piktrograf, karakter alfabet) perekam gagasan dapat diaktualisasikan. Kemudian Danesi membagi media ke dalam tiga kategori dasar, yaitu medium alami, medium buatan, dan medium mekanis. Medium alami yaitu yang memancarkan gagasan dengan cara berbasis biologis (melalui suara, ekspresi wajah, gerakan tangan dan sebagainya). Medium buatan, bagaimana gagasan direpresentasikan dan dikirimkan menggunakan suatu artefak tertentu (buku, lukisan, patung, surat, dan sebagainya). Sedangkan medium mekanis, bagaimana gagasan dikirimkan dengan menggunakan 
peralatan mekanis temuan manusia seperti telepon, radio, pesawat televisi, komputer dan sebagainya (Danesi, 2010: 8).

Pembagian media menurut Danesi tersebut sekiranya sejalan dengan gagasan Ong tentang Orality (kelisanan), Literacy (keberaksaraan), dan Secondary Orality (kelisanan kedua) (Ong, 2005). Jika pembagian media yang dilakukan Danesi dapat ditangkap sebagai tataran perubahan bentuk bagaimana gagasan-gagasan disampaikan dari kurun waktu yang satu ke kurun waktu yang lain, maka Ong lebih mencoba untuk berbicara tentang pengaruh apa yang muncul pada masyarakat yang mengalami perubahan bentuk penyampaian gagasan-gagasan tersebut, sebagaimana yang dikatakannya pada bagian pengantar buku Orality And Literacy:

The shift from orality to literacy and on to electronic processing engages social, economic, political, religious and other structures. These, however, are only indirect concerns of the present book, which treats rather the differences in 'mentality' between oral and writing cultures (1982: 3).

Gagasan Ong ini kemudian juga terasa titik temunya kembali dengan apa yang disampaikan Danesi pada bab 1 bukunya Understanding Media Semiotics (2010: 18) bahwa perjalanan singkat sepanjang sejarah media memberikan pelajaran berharga, yaitu bahwa perubahan besar dalam cara merepresentasikan dan mengirimkan informasi menghasilkan pergeseran paradigma yang berkaitan dalam sistem-sistem budaya.

Terjadinya peralihan dari masa kelisanan ke masa keberaksaraan yang disambut cepat pula oleh masa elektronik memberikan dampakdampak tertentu pada masyarakat dan hasil karya (fokus pembahasan: karya sastra) masyarakat (dalam hal ini sastrawan) yang disinggahinya, tak terkecuali pula Riau. Riau memiliki tradisi lisan yang kuat bahkan sampai sekarang pun pada beberapa tempat tradisi lisan itu masih tersisa. Hal ini dapat dilihat 
dari kebiasaan bepantun dan terdapatnya berbagai cerita-cerita lisan dalam masyarakat. Kelisanan hampir melekat pada setiap tradisi kehidupan masyarakat melayu dulu mulai dari kelahiran sampai kematian. Dampak dari kelisanan yang kuat ini adalah sebuah kekolektifan dan pola pandang yang sama terhadap sesuatu. Dan agaknya bisa dikatakan kalau masyarakat lisan lebih memiliki sebuah identitas yang kokoh dan jelas sehingga masalah identitas bagi mereka bukanlah sesuatu yang dipentingkan lagi. Mereka tinggal menjaga dan menjalani apa yang telah mereka bentuk dalam kurun waktu yang lama. Kemudian selanjutnya masyarakat lisan ini bersentuhan dengan keberaksaraan yang salah satu cirinya menurut Teeuw adalah lebih mengutamakan indera penglihatan. Indera penglihatan ini menurut Teeuw lagi cenderung memecahbelahkan dan mengindividualkan, namun dampak positifnya manusia bisa keluar dari kotak-kotak pemikiran yang sama sehingga mampu mengeluarkan pemikiran-pemikiran baru yang bisa menyumbangkan sesuatu pada perkembangan peradaban manusia selanjutnya.

Akibat peralihan tersebut, agaknya berpengaruh pula pada tema yang cendrung diangkat oleh para sastrawan Riau modern (generasi setelah Raja Ali Haji) pada karya-karyanya. Dan membaca karya-karya penyair Riau maka tema yang cenderung muncul adalah tentang kemelayuan, yaitu semacam upaya untuk memperjelas sebuah identitas yang bernama melayu. Lalu, pertanyaan-pertanyaan yang muncul. Mengapa tema kemelayuan yang cendrung diangkat oleh penyair-penyair Riau dan apakah hubungannya dengan munculnya keberaksaraan? Bagaimana gambaran melayu yang mereka berikan dan kemungkinan apa disebalik penggambaran yang mereka berikan? Dan kalau dilihat dari cara mereka melakukan penyebaran karya yaitu dengan menembus koran-koran (media massa) lokal dan nasional, ada hal apa kiranya dibalik itu? 
Untuk menjawab pertanyaanpertanyaan tersebut maka objek kajian yang digunakan yaitu sajak dari Taufik Ikram Jamil dan Marhalim Zaini. Alasan pemilihan, karena masing-masing penyair tersebut memiliki ciri khas penulisan kemelayuan yang kental. Selain itu para penyair ini muncul dalam waktu yang berbeda sehingga dirasa bisa mewakili generasi sastrawan Riau (setidaknya). Taufik Ikram Jamil lebih dulu muncul dengan tema kemelayuannya baru kemudian Marhalim Zaini muncul. Kedua penyair ini sama-sama bisa 'menasional' dengan ciri khas sajaksajak mereka yang begitu kental dengan nuansa Melayu.

\section{PEMBAHASAN}

Masyarakat lisan dulu, menurut penulis tidak lagi mempermasalahkan soal identitas, karena mereka sudah merasa memiliki identitas yang jelas dan sudah selesai. Hal ini bisa dilihat dari cerita-cerita lisan, misalnya cerita tentang Bujang Tan Domang dalam Nyanyi Panjang, sastra lisan masyarakat Melayu-Petalangan. Dalam cerita tersebut dikisahkan bahwa Bujang Tan Domanglah yang merupakan cikal bakal masyarakat Petalangan, seorang manusia yang luar biasa, arif bijaksana lagi sakti mandraguna yang menetapkan segala hukum adat demi kebaikan dan kemakmuran masyarakat Petalangan. Kebesaran Bujang Tan Domang serta segala nilai-nilai dan hukum adat yang terdapat di dalam kisah tentangnya, dipelihara secara terus-menerus dengan sungguhsungguh oleh seluruh masyarakat. Tugas sebagai penyampai cerita tersebut ditanggung oleh mereka yang disebut Pebilang Tombo.

Masyarakat lisan ini dengan kekolektifan yang tinggi dan persentuhan yang tidak banyak dengan budaya-budaya lain di sekitarnya maka menurut penulis persoalan identitas bagi mereka sudah selesai (hal yang tidak perlu), dan tugasnya tinggal memelihara apa yang sudah ada, apa yang sudah dibentuk. Dan karya-karya sastra lisan yang dihasilkan fungsinya lebih pada sebagai kontrol nilai 
terhadap masyarakat pemiliknya. Namun, pada perjalanan selanjutnya masyarakat Melayu pun juga turut bersentuhan dengan keberaksaraan, bersentuhan dengan budaya-budaya lain, dan sehubungan dengan kondisi sumber daya alam Riau yang kaya menyebabkan Riau banyak didatangi oleh orang luar yang mau tidak mau maka terjadilah percampuran-percampuran sehingga memunculkan perubahan keadaan. Selain itu hal historis yang berhubungan dengan penanda tanganan Tracktat London 1824 yang mengakibatkan pecahnya wilayah melayu menjadi negaranegara yang berbeda menjadi sejarah yang selalu saja diratapi oleh para penyair-penyairnya. Singkatnya peralihan masa lisan ke masa keberaksaraan yang berhubungan pula dengan perubahan struktur politik, ekonomi, dan sistem budaya (Danesi, 2010: 18) menurut penulis menyebabkan munculnya wacana tentang kemelayuan, wacana tentang identitas. Para penyair Riau modern (setelah generasi Raja Ali Haji) telah masuk pada pola pikir keberaksaraan sehingga muncul pertanyaan-pertanyaan tentang dirinya sendiri. Seperti apakah Melayu, apa yang dialami oleh Melayu, ada apa dan mengapa. Sekiranya hal tersebutlah yang dapat kita lihat pada dua sajak berikut :

\section{Sajak Marhalim Zaini}

Seribu Lima Ratus Sebelas

seribu lima ratus sebelas di dinding gereja merah saga burung-burung hitam melepas gaun melaka. tembok meninggi membangun ritus di kaki langit tua aku menurunkan gumpalan kota dari pundak malam yang memberat di anak tangga ke tujuh pada dingin yang disalibkan.

aku tamu berharap bertemu separuh tubuhku di tanah bekas waktu menurunkan gerimis menjejakkan kaki portugis tapi tangis itu tangis itu juga yang mencumbu menggelapkan segala peluk pada kutuk ia hinggap di ujung-ujung rambutku membangun jembatan rumpang ke masa lalu. 
ia menungguku dentang jam pada lengang mengirimkan becak penuh bunga seorang tua menebak wajah sejarah di raut asing bahasa lautku tapi ia tahu di jalan lurus yang kurus sebuah kota sedang bekerja membuat pagar dari kaki-kaki pendatang yang kekar turunkan aku di sini, tuan

di mana rumah itu tempat kebisuan dibatukan gedung tua saling pandang membuat tubuhku terasa telanjang aku takut menyebut siak mulutku tertinggal di kursi retak aku ragu memanggil lingga lambaiku tersangkut di singapura duhai jauhlah badan di tanah orang berebut rumah di negeri sendiri

pada senja tua burung-burung hitam melepas seribu lima ratus sebelas gaun melaka

di bawah tembok gereja yang meninggi aku membangun ritus merah saga di kota-kota tua di anak tangga ke tujuh pada dingin malam yang disalibkan.

Melaka, 2004-2008

(http://www.jurnalnasional.com/)
Sajak Taufik Ikram Jamil

Datang ke Bengkalis

tak banyak yang berubah di sini cuma saja

kita tak bisa membelek-belek harapan sementara kenangan adalah hantu menyemburkan kepedihan

dari semua waktu

di jalan yani dan pattimura dan hasanudin dan hang tuah dan damon

masih terdengar keriut sepeda norton

lengkingan ibu zam

pujuk rayu ibu tin

tapi air mata

air matamu kini menitik ke hatiku

tak banyak yang berubah di sini cuma saja

tapak kita kian terpuruk dilindas aspal

sebelum saatnya menjadi minyak bumi

yang seperti biasa

'kan ditambang tanpa kasih

tapi sang geolog

di ladang-ladang texas sampai minas tak mampu mengurai kita

karena rindu itu

tak pernah diselesaikan

tidak akan pernah diselesaikan

(dari antologi puisi Tersebab Haku

Melayu)

Pada sajak Seribu Lima Ratus

Sebelas gambaran melayu yang bisa 
dirasakan yaitu melayu yang patah, yang berubah wajah, yang menyimpan sejarah luka. Kegagahan melayu pada masa kerajaan dulu berubah menjadi Melayu yang terpecah yang tidak lagi dihuni dan dikuasai oleh orang-orang Melayu namun malah orang-orang dari suku bangsa lain yang mampu mengubah hidup mereka ke arah yang jauh lebih baik dibandingkan masyarakat melayu asli yang dianggap pemilik syah tanah melayu tersebut. Menjadi terasing di tanah sendiri adalah hal yang dirasakan si aku pada sajak Marhalim di atas. Sejarah yang sering diratapi yaitu runtuhnya Malaka pada tahun 1511, ketika Malaka dikuasai oleh Portugis. Hal ini pulalah yang diangkat Marhalim. Selain peristiwa 1511 ini, peristiwa yang dianggap sebagai pecahnya melayu adalah penandatangan Tracktat London Antara Belanda dan Inggris pada tahun 1824, yang mana membelah wilayah budaya melayu menjadi dua. Riau menjadi milik Belanda sedangkan Singapura dan Malaysia sekarang menjadi milik Inggris. Hal ini pulalah yang diyakini sebagai awal perubahan peradaban melayu ke depan sehingga Marhalim berujar :

di mana rumah itu tempat kebisuan dibatukan gedung tua saling pandang membuat tubuhku terasa telanjang aku takut menyebut siak mulutku tertinggal di kursi retak aku ragu memanggil lingga lambaiku tersangkut di singapura duhai jauhlah badan di tanah orang berebut rumah di negeri sendiri

Seorang Melayu yang gamang karena merasa asing di tanahnya sendiri, hal itulah yang terasa dari bait puisi di atas. Nuansa kesedihan dan duka lara begitu terasa dari pilihan diksi yang digunakan. Orang yang meratap.

Kemudian hal yang lebih kurang sama tergambar pula pada sajak Taufik Ikram Jamil, Datang ke Bengkalis.

tak banyak yang berubah disini cuma saja kita tak bisa membelek-belek harapan sementara kenangan adalah hantu menyemburkan kepedihan dari semua waktu 
Lagi-lagi adalah sesosok anak Melayu yang pedih perih karena kenangan, yang tidak punya liang tempat menanam harapan. Taufik memilih kata datang pada judul puisinya bukan pulang sementara Bengkalis adalah tanah kelahirannya. Mengapa kiranya seseorang membahasakan dirinya sebagai orang yang datang ke rumahnya sendiri, bukan sebagai orang yang pulang? Ibarat seorang dagang begitulah kiranya Taufik memposisikan dirinya. Senantiasa melakukan perjalanan untuk menemukan keberadaannya. Karena keberadaan yang dulu sudah sama sekali berbeda dengan keberadaan kini. Dan ketika kesadaran itu muncul maka kenangan adalah hantu/menyemburkan kepedihan/ dari semua waktu.

Pada kedua puisi ini maka kesadaran akan masa lalu samasama hadir. Marhalim pecah tangis membangun jembatan rumpang ke masa lalu. Begitu pula Taufik yang larut pada kenangannya tentang Bengkalis. Bengkalis yang ia tinggalkan yang kemudian ia datangi kembali ternyata tetap berwajah sama, tidak banyak yang berubah melainkan cuma tapak kita kian terpuruk dilindas aspal/ sebelum saatnya menjadi minyak bumi/ yang seperti biasa/ 'kan ditambang tanpa kasih. Dari baris-baris sajak Taufik ini juga terdapat gambaran betapa melayu dalam segi perekonomian tidak kemana-mana sementara sumber daya alamnya begitu kaya. Minyak bumi yang ia kandung ternyata hanya dinikmati oleh orang lain yang menambangnya tanpa kasih. Melayu yang dulu gagah berubah menjadi Melayu yang kalah dan larut dalam kemiskinankemiskinannya sendiri di tengah kekayaan-kekayaan yang mereka miliki. Sesuatu yang membuat getir para penyair-penyair Melayu sehingga mereka selalu menyuarakan hal tersebut pada karya-karya mereka, baik sajak, cerpen maupun novel.

Gagasan tentang kemelayuan yang seperti itu dimediasikan dalam karya-karya sastra mereka. Gambaran tentang keMelayuan yang mereka alami dan mereka 
sampaikan disebarkan dengan memilih media massa sebagai tempat publikasi. Media massa lokal dan nasional (walaupun mungkin istilah lokal dan nasional sekarang sudah pula dipertanyakan) dipilih sebagai cara merepresentasikan gagasan mereka tentu bukan tanpa maksud. Hal ini tentu berhubungan dengan khalayak pembaca yang dituju. Khalayak pembaca lokal tujuannya adalah untuk penyadaran tentang kondisi kini Melayu agar sekiranya dapat menindaklanjutinya dengan perubahan pola pikir pada diri sendiri (Melayu) sedangkan capaian dari pilihan media massa nasional (seperti Kompas, Jurnal Indonesia dll) adalah semacam usaha perjuangan ideologi kemelayuan mereka agar didengar dan diperhatikan oleh pusat, agar perekonomian dan keadilan sosial tak lagi timpang, agar kekayaan yang dimiliki Riau tidak sematamata dikeruk semena-mena tanpa memikirkan nasib dari orang-orang yang dikeruk.

\section{SIMPULAN}

Dari pembahasan singkat di atas, agaknya kita bisa melihat bagaimana peralihan kelisanan dan keberaksaraan juga berpengaruh pada fungsi sastra yang akan berdampak pula pada bentuk sastra yang dihasilkan juga tema-tema yang diangkat. Dalam konteks Riau maka tema yang cenderung diangkat adalah tentang kemelayuan yang ditampilkan dengan sajak-sajak nada minor (meminjam istilah seorang kawan). Sajak-sajak yang meratap namun penuh amuk yang terpendam menungguh pecah. Kemungkinan pengangkatan tema kemelayuan seperti ini pertama adalah sebagai bentuk usaha penyadaran diri tentang identitas kemelayuan yang sedang dialami (dengan memilih media massa lokal) dan sebagai perjuangan ideologi kemelayuan untuk mendapatkan pengakuan dan perhatian dari pusat (dengan memilih media massa nasional).

Namun, jika dari masa ke masa sajak-sajak yang dihasilkan tetaplah sajak-sajak bernada minor 
yang berasyik makhsyuk dengan persoalan identitas kemelayuan yang tak pernah usai, memanglah pula alamat kapal Melayu selalu berlayar malam, berkelam-kelam dengan ratapan diri sendiri.

\section{DAFTAR PUSTAKA}

Danesi, Marcel. 2010. Pengantar Memahami Semiotika Media. Yogyakarta: Jalasutra

Effendy, Tennas. 2008. Bujang Tan Domang. Jakarta: Yayasan Obor Indonesia

Jamil, Taufik Ikram. 1995. Tersebab Haku Melayu. Pekanbaru: Yayasan Membaca
Koentjaraningrat, dkk. 2007. Masyarakat Melayu dan Budaya Melayu dalam Perubahan. Yogyakarta: Balai Kajian dan Pengembangan Budaya Melayu.

Ong, Walter J. 1982. Orality and Literacy: The Technologizing of the Word. New York: Methuen \& Co.

Teeuw, A. 1994. Indonesia Antara Kelisanan dan Keberaksaraan. Jakarta: Pustaka Jaya.

http://www.jurnalnasional.com/ 